\title{
Reasoning Model and Moral Simulation to Improve Students' Social Skills: A Focused Look at Emotional Intelligence
}

\author{
Risma Margaretha Sinaga ${ }^{1^{*}}$ \\ Albet Maydiantoro ${ }^{1}$ \\ Onojah Amos Ochayi ${ }^{2}$ \\ Dwi Yulianti ${ }^{1}$ \\ Suparman Arif ${ }^{\prime}$ \\ Muhammad Basri ${ }^{1}$ \\ John Rainer T. Bolado3 \\ Suroto \\ ${ }^{1}$ Faculty of Teacher Training and Education Universitas Lampung, \\ Jl. Prof.Dr. Ir. Sumantri Brojonegoro No.1, Gedong Meneng, Rajabasa, \\ Bandar Lampung City, Lampung 35145, Indonesia \\ ${ }^{2}$ Faculty of Education University of Ilorin P.M.B 1515, City of Ilorin, Kwara State, Nigeria \\ ${ }^{3}$ San Agustin Integrated School, Philippine Department of Education, \\ San Agustin Road, San Fernando City, Philippines \\ ${ }^{*}$ Corresponding Author
}

DOI: https://doi.org/10.36941/jesr-2022-0026

\section{Abstract}

Education serves the purpose of cultivating the capacity to shape character and civilisation in a dignified manner to advance the nation's intellectual life. Social studies education is an affective domain subject because it teaches students to see knowledge in social interactions and to apply it directly in the community environment. This study compares students' social skills acquired through moral reasoning-based cooperative learning to those acquired through simulation-based cooperative learning in order to determine the effectiveness of simulation-based and moral reasoning-based cooperative learning in improving students' social skills, as well as the interaction between the two. This research employed a quasi-experimental design with a comparative approach. The study was conducted in classes VIII A and VIII B, with 27 students and 26 students, respectively, at SMP N 27 Pesawaran, Lampung Province, Indonesia. The findings of this study indicate a significant difference in social skills between students taught using the Moral Reasoning cooperative learning model and students taught using the Simulation cooperative learning model in social studies subjects. Learning that employs the Moral Reasoning learning model is more effective than learning that employs the Simulation one.

Keywords: moral reasoning model, simulation model, social skills, social studies 


\section{Introduction}

Education plays a critical role in a nation's development. Its purpose is to foster the capacity for dignified shaping of character and civilisation through the development of the nation's intellectual life (Nurdin, 2015; Tyas et al., 2020). Education is a deliberate and planned effort to foster an environment conducive to learning and learning behaviour for students to develop their potential actively. It aims to develop people who believe in and have faith in God, have a noble character, are healthy, knowledgeable, capable, creative, and independent, and who become democratic citizens. A school is a place where students can develop their cognitive, affective, and psychomotor abilities in order to successfully complete life's tasks (Cooper \& Higgins, 2015). However, education now places a greater emphasis on cognitive skills than on affective and psychomotor abilities. One of the domains that must be considered is the affective domain. The affective domain encompasses behaviours that emphasise emotional aspects, such as interests, attitudes toward something, appreciation, selfawareness, and a student's social skills. Education is implemented in schools through teaching and learning interactions or through learning (Kurniati et al., 2020).

Numerous previous studies indicated that students' social skills could be enhanced (Gates et al., 2017; Lewallen \& Neece, 2015; Park, 2017). As a result, an appropriate learning model is required to apply a cooperative learning model in social knowledge subjects in junior high schools to improve student skills.

\section{Literature Review}

\section{$2.1 \quad$ Social studies learning}

Because social studies educate students to see knowledge in socialising and have to apply it directly in the community environment, it tends to be an affective domain subject (Boyle et al., 2007; O'Shea et al., 2015; Uge et al., 2019). Students must develop an awareness and concern for the environment and an understanding of the values inherent in the community's cultural history and the school environment, such as greeting classmates before entering class and showing respect for the teacher while learning.

Susanto (2016) states that the objectives and scope of social studies education are to have a conceptual understanding of life and the community environment, to possess essential skills such as curiosity, research, problem-solving, and social life skills for logical and critical thinking, to have an awareness of and commitment to social and human values, and to have the ability to communicate, cooperate, and compete locally and globally in a pluralistic society.

Social studies education plays a critical role in the development of a country. A high-quality social studies education will undoubtedly produce a nation that prioritises the country's development in accordance with social studies education's objectives. Social studies education is necessary to contribute optimally to the improvement of educational quality. To achieve directed, planned, and sustainable education, all parties must take an active role, including the government, teachers, parents, and others.

\subsection{Social Skills}

Social skills are the capacity to develop harmonious and satisfying social relationships, influence the social environment, and solve social problems. They include the capability to build aspirations and present themselves with mutual respect, independence, life goals, discipline, and decision-making. Communication skills, self-management, conflict resolution, and friend situations are examples of social skills. Social skills development is critical for students because it can help them develop an awareness of their behaviour, both in terms of quality with others, modes of communication, forming mutually reinforcing groups, trusting one another, and the extent to which an individual can solve 
problems.

Social skills refer to students' abilities to locate themselves and assume appropriate roles in their environment. In line with that, Morris et al. (2017) stated that social skills refer to an individual's or community member's capacity to form relationships and resolve conflicts in order to coexist harmoniously with the surrounding community. This viewpoint is consistent with (Arends, 2008), that social skills contribute to the success of social relationships and enable individuals to collaborate effectively with others.

Social abilities are pretty similar to other skills such as cooperating with peers, joining groups, making new friends, and collaborating. Lack of social skills has a negative impact on these students' academic achievement, they are often lonely and have low self-esteem, and there is a risk of dropping out of school (Muijs \& Reynolds, 2008).

Numerous tools, such as questionnaires, observation sheets, self-report checklists, and rating scales, can be used to assess students' social skills. Each instrument is grouped according to the dimensions of social abilities. (Jurkowski \& Hänze, 2017) define social skills in five dimensions: 1) interpersonal skills, 2) self-management skills, 3) academic skills, 4) rule compliance skills, and 5) assertion skills.

\subsection{Cooperative Learning Model}

The cooperative learning model empowers students to be more active and dominant in the learning process than the teacher. Apart from fostering positive interactions, cooperative learning aims to develop strong personalities and a sense of responsibility. It is in the groups' best interests to ensure that all members care about their characters by developing their ability to work collaboratively. Educators can utilise a variety of learning models, including moral reasoning and simulation models. According to Lagnado and Gerstenberg (2017), the moral reasoning learning model is a cooperative learning model. It is based on ethical dilemmas, and the discussion was conducted using a group discussion method, with an emphasis on three critical conditions. First, it motivates students to develop a higher level of moral judgement. Second, there is a hypothetical and real dilemma involving everyday values. Thirdly, an atmosphere conducive to productive discussion.

According to Zech et al. (2018), the simulation-based learning model is group-based, and students develop teaching and communication skills in small groups through simulation-based learning. Oxelmark et al. (2017) stated that simulated learning tasks could be designed. The form is designed in such a way that it is not overly complicated in the real world, making it easy to quickly master or learn the feedback developed by students about how they communicate. Finally, it has the potential to bring academic learning to life.

According to Parsazadeh et al. (2018), the simulation model can be used to guide student cooperation training, mutual respect, and skill development. This simulation-based learning model is believed to be beneficial for training and developing social skills. Ineffective teachers can result in ineffective students' social skills, which is frequently the case due to various factors.

\subsection{Emotional Intelligence}

Along with the learning model, it is believed that students' emotional intelligence has an effect on their social skills. Emotional intelligence significantly impacts students' social skills, motivating and guiding them. Managing emotions effectively when interacting with others is a skill that can help improve social skills. Emotional intelligence can help students develop their social skills by enhancing moral reasoning and simulation learning models.

The term emotional intelligence was first introduced by Piter Salovey from Harvard University and John Mayer from New Hampshire (WajdI et al., 2018). This concept is rapidly evolving because it is a component of shaping intelligent behaviour. According to Elfenbein and MacCann (2017), emotional intelligence is the capacity to confront one's emotions and use them to guide one's 
thoughts and actions. According to Miao et al. (2017), Emotional intelligence is the capacity to recognise one's own and others' emotions, motivate oneself, and organise one's own and others' emotions effectively.

This study aimed to compare the social skills of students who learned using the moral reasoning learning model to those who learned using the simulation learning model. It also examined how learning models and emotional intelligence interact to affect students' social skills and the effectiveness of learning from simulation and moral reasoning in improving students' social skills.

\section{Research Methods}

\subsection{Research Model}

This study used a quasi-experimental approach with a comparative approach. The research design used is a research design that compares the effectiveness of two learning models, namely Moral Reasoning (MR) and Simulation (SM), on students' social skills, with the hypothesis that by paying attention to students' emotional intelligence, this learning method may have a different effect on students' social skills. In practice, the control class followed the moral reasoning learning model, while the experimental class followed the simulation learning model, emphasising emotional intelligence.

Table 1: Pretest-Posttest Research Design with Unequal Groups

\begin{tabular}{|l|c|c|c|}
\hline Category & pre-test & Treatment & post-test \\
\hline Group 1 & $\mathrm{O}_{1}$ & $\mathrm{X}_{1}$ & $\mathrm{O}_{3}$ \\
\hline Group 2 & $\mathrm{O}_{2}$ & $\mathrm{X}_{2}$ & $\mathrm{O}_{4}$ \\
\hline
\end{tabular}

Source: (Cohen et al., 2017)

Information: $\mathrm{O}_{1}$ and $\mathrm{O}_{2}$ : Measurement of social skills before treatment (pre-test), $\mathrm{O}_{3}$ and $\mathrm{O}_{4}$ : Measurement of social skills after treatment (post-test).

$\mathrm{X}$ : Social studies learning with Moral Reasoning learning model

$\mathrm{X} 2$ : Social studies learning with simulation learning model

According to Sugiyono (2009), experimental research is a technique for determining specific influences on other people in uncontrolled circumstances. There are several series of activities in data collection in this study, with the steps listed below:

The experimental group, the control group, and the class/treatment group were all determined.

The first round of observations and questionnaires were completed. Prior to starting treatment, the two activities were conducted to determine the students' initial abilities. Initial observations were made in order to assess social skills while also considering emotional intelligence.

Learning process in the treatment class.

Learning process in the treatment class.

Learning process in the control class.

Observations and distribution of the final questionnaire after treatment. Students' abilities were assessed through observation. After being treated with attention to their emotional intelligence, students were given a final questionnaire to determine their social skills.

Following the collection of data from respondents and other data sources, data analysis was carried out.

\subsection{Population and Sample}

This study's population is made up of three classes from class VIII SMP N 27 Pesawaran, Lampung Province, Indonesia. The cluster sampling technique was used to select the sample for this study, 
which consisted of two classes, class VIII A with 27 students and class VIII B with 26 students.

\subsection{Data collection technique}

This study adopted a non-test data collection technique. The observation of students' social skills was used as a non-test process. Forming groups, appreciating contributions, taking turns and sharing tasks, being in groups, encouraging participation, tolerance, and communicating are aspects of social skills that observation sheets and assessment rubrics measured.

Table 2: Aspects and Indicators of Social Skills

\begin{tabular}{|c|l|l|}
\hline No & \multicolumn{1}{|c|}{ Aspect } & \multicolumn{1}{|c|}{ Indicator } \\
\hline 1 & Forming groups & Forming groups \\
\hline 2 & Appreciating the contributions of other members. & Appreciating the contributions of group members \\
\hline 3 & Taking turns/sharing tasks. & Taking an active role in a group \\
\hline 4 & Being a part of a group & Being in a group during learning \\
\hline 5 & Tolerance & Respect for differences within the group \\
\hline 6 & Encouraging the participation of other members. & Encouraging the participation of other members \\
\hline 7 & Communicating & Communicating ideas well \\
\hline
\end{tabular}

\subsection{Data analysis}

The descriptive analysis stage and hypothesis testing were used to see how the influence of Moral Reasoning and Simulation model learning on students' social skills changed over time for each class of analysis. The descriptive analysis stage of the social skills assessment analysis was the first stage, and the hypothesis testing was the next step. We used an independent sample T-test for each group to test the hypothesis. The SPSS 25 was used to perform hypothesis testing. A normality test was performed previously to check whether the data was distributed normally. The normality test was performed in both the experimental and control groups, with the following results.

Table 3: The Normality Test

\begin{tabular}{|l|c|c|c|c|}
\hline Test Group & Category & $\alpha_{\text {count }}$ & $\alpha_{\text {table }}$ & Information \\
\hline Experimental Group & pre-test & 0.1485 & $\mathbf{0 . 2 3 4}$ & Normally Distributed \\
\hline & post-test & 0.1566 & $\mathbf{0 . 2 3 4}$ & Normally Distributed \\
\hline Control Group & pre-test & 0.1845 & $\mathbf{0 . 2 3 4}$ & Normally Distributed \\
\hline & post-test & $\mathbf{0 . 1 1 2 2}$ & $\mathbf{0 . 2 3 4}$ & Normally Distributed \\
\hline
\end{tabular}

Source: Data Analysis

Table 3 shows that the pre-test experimental group had an $\alpha$ count of 0,1485 , the post-test experimental group had an $\alpha$ count of 0,1566 , the pre-test control group had an $\alpha$ count of 0,1845 , and the post-test control group had an $\alpha$ count of 0,1122 . It is concluded that the data distribution of the social skills variable is normally distributed when all count tables are significant at the level of 0.05 (o.234).

The following are the hypotheses that have been proposed.

Ho: By paying attention to students' emotional intelligence, the Moral Reasoning learning model has no greater influence on social skills than the simulation learning model.

Ha: By focusing on students' emotional intelligence, the Moral Reasoning learning model has a greater impact on social skills than the Simulation learning model.

Or they can be written as follows: 
Ho: $\mu \mathrm{A} \leq \mu \mathrm{B}$

Ha: $\mu \mathrm{A}>\mu \mathrm{B}$

By looking at the sig value, the decision was made at the $5 \%$ significance level. If the value is sig., Ho is rejected, indicating that the moral reasoning learning model has a greater impact on students' social skills than simulation.

Table 4: Social Skills Score in Achievement Categories

\begin{tabular}{|c|l|l|}
\hline No & Score scale & Criteria \\
\hline 1 & $\mathrm{X} \leq 43.75$ & Very low \\
\hline 2 & $43.75<\mathrm{X} \leq 56.25$ & Low \\
\hline 3 & $56.25<\mathrm{X} \leq 68.75$ & Enough \\
\hline 4 & $68.75<\mathrm{X} \leq 81.25$ & High \\
\hline 5 & $\mathrm{X}>81.25$ & Very high \\
\hline
\end{tabular}

Table 4 shows the social skills evaluation score based on the normal distribution model, the range of scores on the rating scale is divided into five achievement criteria. The score summarises study findings on the various effects of adopting the cooperative learning model of moral reasoning and simulation on students' social skills in each class. After that, the MR and SM models' final observation findings were compared.

\section{Result}

\subsection{Preliminary Observation}

Initial observations were made in the two experimental classrooms to ascertain the baseline value of students' social abilities. The groupings were made without regard for cognitive capacities, gender equality, or student communication abilities, but rather on the basis of the student presence serial number. Data on the value of students' social skills were collected from observations of students' social skills during the course of their learning. The pre-test value was derived from comments made by members of the two experimental courses and then transformed into a learning model. Table 5 summarises the significance placed on social skills by students in both classes.

Table 5: The pre-test scores of students' social skills

\begin{tabular}{|c|l|c|c|}
\hline No & Description & $\begin{array}{c}\text { Experimental Class } \\
\text { (Moral Reasoning) }\end{array}$ & $\begin{array}{c}\text { Control Class } \\
\text { (Simulation) }\end{array}$ \\
\hline 1 & Average & 47.06 & 48.45 \\
\hline 2 & Middle value & 46.33 & 50.04 \\
\hline 3 & Standard Deviation & 7.24 & 7.82 \\
\hline 4 & Variance & 52.67 & 62.65 \\
\hline 5 & Maximum Value & 57.15 & 57.24 \\
\hline 6 & Minimum Value & 35.81 & 35.61 \\
\hline
\end{tabular}

Source: Data Analysis

The observation results indicated that the experimental class's pupils' social skills remained low, as reflected by the acquired social skills assessment. The Experimental Class averaged 47.06, while the Control Class averaged 48.45, placing them both in the low group.

The control class's mean value was higher by 1.39 points, while the maximum value was nearly identical across the two classes, with the experimental class's details being 57.15 and 57.24 points. 


\subsection{Final Observation}

Data on the importance of students' social skills were gathered through observations of students learning in the experimental and control classes. This value was derived from observations of the two classes following their participation in a cooperative learning model of moral reasoning and simulation kinds. Table 6 details the importance of students' social skills in both classrooms.

Table 6: The post-test scores of students' social skills

\begin{tabular}{|c|l|c|c|}
\hline No & Description & Experimental Class & Control Class \\
\hline 1 & Average & 86.14 & 78.78 \\
\hline 2 & Middle value & 86.61 & 81.23 \\
\hline 3 & Standard Deviation & 5.32 & 6.72 \\
\hline 4 & Variance & 29.54 & 46.53 \\
\hline 5 & Maximum Value & 92.86 & 92.86 \\
\hline 6 & Minimum Value & 78.57 & 67.86 \\
\hline
\end{tabular}

Table 6 illustrates the difference in the mean value of social skills between the two classes. The MR class averaged 86.14, while the SM class averaged 78.78. The mean MR grade was 7.36 points higher. Similarly, the minimum score that students in the MR class could get was 10.71 points greater than that of students in the SM class.

\subsection{Hypothesis Testing}

Table 7 below presents the following findings based on the results of hypothesis testing.

Table 7: Hypothesis Testing Results

\begin{tabular}{|c|c|c|c|c|c|c|c|c|c|c|}
\hline & \multicolumn{6}{|c|}{ Levine's Test for Equality of Variances } & \multicolumn{3}{|c|}{ t-test for Equality of Means } \\
\hline & & \multirow[t]{2}{*}{$\mathrm{F}$} & \multirow[t]{2}{*}{ Sig. } & \multirow[t]{2}{*}{$\mathrm{t}$} & \multirow[t]{2}{*}{ df } & \multirow[t]{2}{*}{ Sig. (2-tailed } & \multirow[t]{2}{*}{$\begin{array}{l}\text { Mean } \\
\text { Difference }\end{array}$} & \multirow[t]{2}{*}{$\begin{array}{l}\text { Std. Error } \\
\text { Difference }\end{array}$} & \multicolumn{2}{|c|}{$\begin{array}{l}95 \% \text { Confidence } \\
\text { Interval of the } \\
\text { Difference }\end{array}$} \\
\hline & & & & & & & & & Lower & Upper \\
\hline $\begin{array}{l}\text { post- } \\
\text { test }\end{array}$ & \begin{tabular}{|l} 
Equal \\
variances \\
assumed
\end{tabular} & .045 & .833 & $7 \cdot 313$ & 69 & .000 & 9.13889 & 1.24968 & 6.64585 & 11.63193 \\
\hline & \begin{tabular}{|l|} 
Equal \\
variances not \\
assumed
\end{tabular} & & & $7 \cdot 320$ & 68.917 & .000 & 9.13889 & 1.24855 & 6.64804 & 11.62973 \\
\hline
\end{tabular}

Source: Data Analysis

The findings indicated that learning models and emotional intelligence had an effect on students' social skills in social studies areas. This is demonstrated by the data obtained using the independent samples t-test method in the SPSS version 22 programme, which indicates that the MR and SM learning models substantially affect students' social skills. The value of $t$ count reflects the model's effect on social skills greater than $t$ table $(7.313>2.024)$. The value of $t$ count demonstrates the model's influence on social skills $>$ t table $(7.320>2.024)$ with a significance level of $0.833<0.05$. 


\section{Discussion}

The results indicated a substantial difference in students' social abilities between those who learned through the Moral Reasoning model and those who learned through the Simulation model. Final observations suggest that students whose learning is based on the Moral Reasoning learning model have higher social skills to those whose learning is based on the Simulation learning model. While the average social skills of students in the experimental and control classes differ, it is essential to remember that all of the models used are intended to develop students' social abilities, and there is no perfect learning model. These have a benefit, and their disadvantages vary according to the correctness of the material, the location, and the students' circumstances (Maydiantoro, 2020).

Additional research revealed that pupils in the experimental class with a high level of emotional intelligence possessed higher social skills than those in the control class. Social abilities of students whose learning is based on Moral Reasoning are higher than those of students whose learning is based on Simulation in social studies areas with a high level of emotional intelligence. Emotional intelligence refers to the capacity for self-motivation, problem-solving, and heart control. This is an innate talent that enables someone with a high level of emotional intelligence to mobilise their physical and mental capabilities in order to carry out specific tasks. This aligns with Slavin (2015) that cooperative learning entails collaborating to accomplish a common goal. This communication can be said to follow a model of learning that fosters cooperative tolerance and has an effect on students with high emotional intelligence's social skills.

In students with poor emotional intelligence who studied social studies, the results indicated that students who learnt through Simulation had stronger social skills than students who learned through Moral Reasoning. According to the study, students' social skills are higher when they are taught using the Simulation type of reasoning than when they are taught using the Moral type of reasoning in social studies areas. Low emotional intelligence refers to the inability to inspire oneself, solve issues quickly, and develop attitudes that allow pupils' social abilities to remain intact. This is similar to Yonck's (2020) finding that when a person's Emotional Intelligence is low, he or she will act explosively and destructively when disappointed or inadequate. According to Shaughnessy and Boerst (2018), Simulation Learning is a method of instruction in which the teacher poses questions, guiding and eliciting students' ideas. The term "Simulation Learning" refers to a fictitious teaching activity. (Au et al., 2016). All pupils who can tolerate the learning material have been assigned their individual roles in the student simulation learning process. Thus, this learning model can help students develop their courage to communicate and teach them to be responsible for their group members; for students with high social intelligence but low emotional intelligence, the simulation learning model can help them develop social skills while also increasing their social skills their emotional intelligence.

Emotional intelligence is inextricably linked to cooperative learning, as the purpose of cooperative learning is to develop students' capacity for collaborative learning (Dolev \& Leshem, 2017; Estrada et al., 2021). Students with varying levels of emotional intelligence can support and assist one another for the cooperative learning model to function well. The learning model is a technique that teachers use to help students meet specific learning objectives, one of which is social skills.

According to constructivism, which literally translates as "construction," knowledge is constructed by humans incrementally, with the results being extended beyond a narrow context. Through genuine experiences, humans must develop that knowledge and give it significance. Beginning the learning process successfully requires pupils to comprehend their environment and themselves (Burr, 2015; Maydiantoro et al., 2021). Learning, according to behavioristic learning theory or behaviour flow, is described as the process through which behaviour changes as a result of the interplay between stimulus and response. This suggests that the Moral Reasoning learning model and the simulation learning model were used in this study as successful learning models aimed at improving students' social skills (Mazur, 2016).

Improved social skills will emerge from learning using the Moral Reasoning or Simulation models. This indicates a relationship between the learning model used and the students' social skills. 
There is also the possibility of applying social skills in opposite directions, with social skills in Moral Reasoning learning being stronger in students with high emotional intelligence toward social studies subjects and social skills in Simulation learning being stronger in students with low emotional intelligence toward social studies subjects, which explains why the Moral Reasoning and Simulation learning models interact (Alanazi et al., 2017; Bücker \& Korzilius, 2015; Jensen \& Konradsen, 2018).

\section{Conclusion}

The findings indicate substantial disparities in students' social abilities between those who learned through the Moral Reasoning model and those who learned through the Simulation model. Final observations suggest that students whose learning is based on the Moral Reasoning learning model have higher social skills than those whose learning is based on the Simulation learning model.

Further research revealed that pupils in the experimental class who have a high level of emotional intelligence possessed higher social skills than those in the control class. Students' social skills are greater in courses requiring moral thinking when compared to students with high emotional intelligence in social studies areas. Emotional intelligence is the capacity for selfmotivation, problem-solving, and heart control.

Further results showed that students who have low emotional intelligence in social studies subjects showed that students' social skills were higher in students who were taught using the simulation type than in students who were taught using the type of moral reasoning. Then, students' social skills whose learning uses the Simulation type are higher than the Moral Type Reasoning for students with low emotional intelligence in social studies subjects.

Additionally, students with low emotional intelligence in social studies demonstrated that their social skills were higher when taught using the simulation method than the moral reasoning method. Then, for pupils with low emotional intelligence in social studies areas, their social skills are higher when they study through Simulation rather than Moral Type Reasoning.

\section{References}

Alanazi, A. A., Nicholson, N., \& Thomas, S. (2017). The use of simulation training to improve knowledge, skills, and confidence among healthcare students: a systematic review. Internet Journal of Allied Health Sciences Practice, 15(3), 1-24. https://nsuworks.nova.edu/ijahsp/voli5/iss3/2/

Arends, R. I. (2008). Learning to teach: Belajar untuk mengajar. Yogyakarta: Pustaka Pelajar.

Au, M. L., Sao Lo, M., Cheong, W., Wang, S. C., \& Van, I. K. (2016). Nursing students' perception of high-fidelity simulation activity instead of clinical placement: A qualitative study. Nurse Education Today, 39, 16-21. https://doi.org/10.1016/j.nedt.2016.01.015

Boyle, A., Maguire, S., Martin, A., Milsom, C., Nash, R., Rawlinson, S., Turner, A., Wurthmann, S., \& Conchie, S. (2007). Fieldwork is good: The student perception and the affective domain. Journal of Geography in Higher Education, 31(2), 299-317. https://doi.org/10.1080/03098260601063628

Bücker, J. J., \& Korzilius, H. (2015). Developing cultural intelligence: assessing the effect of the Ecotonos cultural simulation game for international business students. The International Journal of Human Resource Management, 26(15), 1995-2014. https://doi.org/10.108o/o9585192.2015.1041759

Burr, V. (2015). Social constructionism. Routledge. https://doi.org/10.4324/9781315715421

Cohen, L., Manion, L., \& Morrison, K. (2017). Research methods in education. routledge. https://doi.org/10.4324/9781315456539

Cooper, D., \& Higgins, S. (2015). The effectiveness of online instructional videos in the acquisition and demonstration of cognitive, affective and psychomotor rehabilitation skills. British journal of educational technology, 46(4), 768-779. https://doi.org/10.1111/bjet.12166

Dolev, N., \& Leshem, S. (2017). Developing emotional intelligence competence among teachers. Teacher development, 21(1), 21-39. https://doi.org/10.1080/13664530.2016.1207093

Elfenbein, H. A., \& MacCann, C. (2017). A closer look at ability emotional intelligence (EI): What are its component parts, and how do they relate to each other? Social Personality Psychology Compass, 11(7), e12324. https://doi.org/10.1111/spc3.12324 
Estrada, M., Monferrer, D., Rodríguez, A., \& Moliner, M. Á. (2021). Does emotional intelligence influence academic performance? The role of compassion and engagement in education for sustainable development. Sustainability, 13(4), 1721. https://doi.org/10.339o/su13041721

Gates, J. A., Kang, E., \& Lerner, M. D. (2017). Efficacy of group social skills interventions for youth with autism spectrum disorder: A systematic review and meta-analysis. Clinical Psychology Review, 52, $164-181$. https://doi.org/10.1016/j.cpr.2017.01.006

Jensen, L., \& Konradsen, F. (2018). A review of the use of virtual reality head-mounted displays in education and training. Education Information Technologies, 23(4), 1515-1529. https://doi.org/10.1007/s10639-017-9676-o

Jurkowski, S., \& Hänze, M. (2017). A closer look at social skills and school performance: students' peer relations skills and assertion skills as predictors for their written and oral performances. European journal of psychology of education, 32(1), 79-95. https://doi.org/10.1007/s10212-015-0284-3

Kurniati, K., Nurdin, N., \& Nurasmawati, N. (2020). Improving Students' Cognitive and Affective Domains Students through Fostering Teacher Development. International Journal of Contemporary Islamic Education, 2(2), 56-70. https://doi.org/10.24239/ijcied.Vol2.Iss2.20

Lagnado, D. A., \& Gerstenberg, T. (2017). Causation in legal and moral reasoning. 565-602. https://psycnet.apa.org/record/2017-30850-029 (Oxford library of psychology. )

Lewallen, A. C., \& Neece, C. L. (2015). Improved social skills in children with developmental delays after parent participation in MBSR: The role of parent-child relational factors. Journal of Child Family Studies, 24(10), 3117-3129. https://doi.org/10.1007/s10826-015-0116-8

Maydiantoro, A. (2020). Penggunaan Model Pembelajaran Kooperatif Tipe Teams Games Tournament Upaya Meningkatkan Pemahaman Belajar. Metafora: Education, Social Sciences Humanities Journal, 1(4), 99-111. https://doi.org/https://doi.org/10.26740/metafora.vin4.p99-111

Maydiantoro, A., Tusianah, R., Isnainy, U. C., Puja Kesuma, T. A. R., Zainaro, M. A., \& Nurmalisa, Y. (2021). A Literature Review of the Three Elements of Organizational Commitment: The Meaning of the Contribution Score Average. WSEAS Transactions on Business Economics, 18, 679-689. https://doi.org/http://doi.org/10.37394/23207.2021.18.67

Mazur, J. E. (2016). Learning $\mathcal{E}$ Behavior: Eighth Edition (8th ed.). Routledge. https://doi.org/ https://doi.org/10.4324/9781315450285

Miao, C., Humphrey, R. H., \& Qian, S. (2017). Are the emotionally intelligent good citizens or counterproductive? A meta-analysis of emotional intelligence and its relationships with organisational citizenship behavior and counterproductive work behavior. Personality Individual Differences, 116, $144-156$. https://doi.org/https://doi.org/10.1016/j.paid.2017.04.015

Morris, T., McGuire, M., \& Walker, B. (2017). Integrating social studies and social skills for students with emotional and behavioral disabilities: A mixed methods study. The Journal of Social Studies Research, 41(4), 253-262. https://doi.org/10.1016/j.jssr.2017.04.001

Muijs, D., \& Reynolds, D. (2008). Effective Teaching Teori dan Aplikasi (terjemahan). Yogyakarta: Pustaka Belajar.

Nurdin, E. S. (2015). The Policies on Civic Education in Developing National Character in Indonesia. International Education Studies, 8(8), 199-209. https://doi.org/10.5539/ies.v8n8p199

O'Shea, S., Stone, C., \& Delahunty, J. (2015). “I 'feel'like I am at university even though I am online.” Exploring how students narrate their engagement with higher education institutions in an online learning environment. Distance Education, 36(1), 41-58. https://doi.org/10.1080/01587919.2015.1019970

Oxelmark, L., Amorøe, T. N., Carlzon, L., \& Rystedt, H. (2017). Students' understanding of teamwork and professional roles after interprofessional simulation-a qualitative analysis. Advances in Simulation, 2(1), 1-8. https://doi.org/10.1186/s41077-017-0041-6

Park, J. (2017). Social Skills Training for Elementary Students with Behavioral Challenges: A review of the Literature. Culminating Projects in Special Education, 43, 1-41. https://repository.stcloudstate.edu/sped_etds/43

Parsazadeh, N., Ali, R., \& Rezaei, M. (2018). A framework for cooperative and interactive mobile learning to improve online information evaluation skills. Computers Education, 120, 75-89. https://doi.org/10.1016/j.compedu.2018.01.010

Shaughnessy, M., \& Boerst, T. A. (2018). Uncovering the skills that preservice teachers bring to teacher education: The practice of eliciting a student's thinking. Journal of teacher Education, 69(1), 40-55. https://doi.org/10.1177/0022487117702574

Slavin, R. E. (2015). Cooperative learning in elementary schools. Education 3-13, 43(1), 5-14. https://doi.org/10.1080/03004279.2015.963370

Sugiyono. (2009). Metodologi Penelitian Pendidikan [Educational Research Methodology]. Alfabeta.

Susanto, A. (2016). Teori belajar dan pembelajaran di sekolah dasar. Kencana. 
Tyas, E. H., Sunarto, S., \& Naibaho, L. (2020). Building Superior Human Resources through Character Education. TEST Engineering Management, 83, 11864-11873. http://repository.uki.ac.id/2871/

Uge, S., Neolaka, A., \& Yasin, M. (2019). Development of Social Studies Learning Model Based on Local Wisdom in Improving Students' Knowledge and Social Attitude. International Journal of Instruction, 12(3), $375-388$. https://doi.org/10.29333/iji.2019.12323a

Wajdİ, M. B. N., Rahayu, S., Ulfatİn, N., Wİyono, B. B., \& Imron, A. (2018). The professional competency teachers mediate the influence of teacher innovation and emotional intelligence on school security. Journal of Social Studies Education Research, 9(2), 210-227. https://dergipark.org.tr/en/pub/jsser/issue/37944/438292

Yonck, R. (2020). Heart of the machine: Our future in a world of artificial emotional intelligence. Arcade.

Zech, J. R., Badgeley, M. A., Liu, M., Costa, A. B., Titano, J. J., \& Oermann, E. K. (2018). Variable generalisation performance of a deep learning model to detect pneumonia in chest radiographs: a cross-sectional study. PLoS medicine, 15(11), e1002683. https://doi.org/10.1371/journal.pmed.1002683 